\title{
The effect of addition of sodium sulphate (Na2SO4) to nickel slag pyrometallurgical process with temperature and additives ratio as variables
}

\author{
Juan Patrick ${ }^{1}$, Agus Budi Prasetyo ${ }^{1}$, Badrul Munir ${ }^{1}$, Ahmad Maksum $^{1,2}$, Johny Wahyuadi Soedarsono ${ }^{1, *}$ \\ ${ }^{1}$ Department of Metallurgical and Materials Engineering, Universitas Indonesia, Depok, 16424, Indonesia \\ ${ }^{2}$ Department of Mechanical Engineering, Politeknik Negeri Jakarta, Depok 16425, Indonesia
}

\begin{abstract}
Nickel industry is one of the most strategic industries because its widely used. Nickel slag as a by-product of nickel processing presents the potential for improving process efficiency. In this study aim to determine the effect of the addition of sodium sulfate additives and also the temperature in the reduction process of nickel slag. The research was preceded by preparation of nickel slag samples with crushing and sieving up to 200 mesh. The nickel slag is then reduced at $800^{\circ} \mathrm{C}, 900^{\circ} \mathrm{C}$ and $1000^{\circ} \mathrm{C}$ temperature without adding sodium sulfate and by adding sodium sulfate with 1 hour holding time. Furthermore, the results of the reduction is done XRD and AAS testing to see changes in the content of elements and compounds in nickel slag that has been tested. The results of the study explain that the content of the dominant impurities which is in the form of $\mathrm{SiO}_{2}$ decreases as the temperature of the reduction and iron from Fe-rich Forsterite compounds will be liberated and will bind to sulfur derived from sodium sulfate to form troilite (FeS). This results in an increasing content of valuable minerals present in the nickel slag.
\end{abstract}

\section{Introduction}

We can say that industry of metal in Indonesia is the catalyst of other industries. Nickel industry is one of the most important metal industries that have many uses in our daily life. There are a variety of nickel products, $62 \%$ of nickel metal is used in stainless steel, $13 \%$ of them is used in super-alloys and nonferrous alloys because it has good corrosion resistance properties and also has good resistance to applications in high temperatures [1].

Nickel ores can be classified into two groups: sulfide ores and laterite ores (oxides and silicates). In fact, $70 \%$ of the nickel mine has a base of laterite ore, but $60 \%$ of the primary nickel production has a sulfide ore base [1]. Processing of nickel ore that is done in Indonesia is nickel in laterite form. This lateritic nickel ore comes from ferro-magnesium silicate minerals commonly found in Sorowako, South Sulawesi[2]. The products of this nickel ore processing process also produce byproducts. This by-product of nickel ore is commonly referred to as nickel slag. Nickel slag is one of the result of processing and smelting of nickel ore. In Indonesia, there is still need for a deeper understanding of the further utilization of nickel slag especially on the processing of the valuable elements contained therein.

The nickel slag, which is the result of the smelting, usually contains some valuable elements such as cobalt, nickel and copper where these valuable elements can exist in the form of sulphides, oxides or free elements [3]. However, the content of these non-ferrous elements is lower when compared to the iron content in the slag so as to enhance this non-ferrous element can be done by the reduction method[3]-[5].

Another content which contained in the nickel slag is fayalite $\left(\mathrm{Fe}_{2} \mathrm{SiO}_{4}\right)$ in which the nickel and copper element distribution is spread evenly on this silica iron matrix which makes it difficult for the process of increasing the nickel and copper content. The addition of sodium sulfate as additive $\left(\mathrm{Na}_{2} \mathrm{SO}_{4}\right)$ serves to bind the silica so it can be used as an alternative method to increase the nickel and copper element content in nickel slag[6]. Additive expected to bind $\mathrm{Fe}$ then form $\mathrm{FeS}$ according to the equation (1), (2), (3), and (4) so that content of $\mathrm{Fe}$ will decrease causing the Ni content to increase.

$\mathrm{FeO}+\mathrm{CO} \rightarrow[\mathrm{Fe}] \mathrm{Ni}+\mathrm{CO}_{2}$

$\mathrm{Na}_{2} \mathrm{SO}_{4}+4 \mathrm{CO} \rightarrow \mathrm{Na}_{2} \mathrm{~S}+4 \mathrm{CO}_{2}(\mathrm{~g})$

\footnotetext{
*Corresponding author: jwsono@metal.ui.ac.id
} 
$\mathrm{Na}_{2} \mathrm{SO}_{4}+3 \mathrm{CO} \rightarrow \mathrm{Na}_{2} \mathrm{O}+\mathrm{S}(\mathrm{g})+3 \mathrm{CO}(\mathrm{g})$

- Binding of $\mathrm{Fe}$ form $\mathrm{FeS}$

$\mathrm{Na}_{2} \mathrm{~S}+\mathrm{FeO} \rightarrow 2 \mathrm{SiO}_{2}+\mathrm{FeS}+\mathrm{Na}_{2} \mathrm{Si}_{2} \mathrm{O}_{5}$

Almost all slags of nickel smelting have the following content of $0.04-1.2 \% \mathrm{Ni}, 0.21-0.7 \% \mathrm{Co}$, and $0.6-3.7 \% \mathrm{Cu}$. While the slag generated from the converter contains $2.87-4.8 \% \mathrm{Ni}, 0.77-1.59 \% \mathrm{Co}$, $0.17-1.4 \% \mathrm{Cu}$. The content of valuable mineral content of both processes has a higher value compared to laterite nickel ore of $1.05-2.3 \% \mathrm{Ni}$ and $0.05-0.3 \%$ Co. The slags derived from nickel contain more than $98 \% \mathrm{Fe}$ and $\mathrm{Co}$, and $54-95 \% \mathrm{Ni}$ and $\mathrm{Cu}$ in the oxide form depending on the treatment method and the type of the furnace. Whereas, there are less than $2 \% \mathrm{Fe}$ and $\mathrm{Co}$, and $4-5 \% \mathrm{Ni}$ and $\mathrm{Cu}$ in sulfide form[7]. Based on these data, when compared with laterite ore, nickel slag can be one source of precious metals because it has a high content of nickel and copper.

\section{Materials and method}

\subsection{Materials}

The sample used in this research is nickel slag powder originating from Sulawesi. The sample preparation is the initial characterization process using XRF, ICP, and XRD. Preparation of samples to be performed before undertaking the study is a reduction in the size of the nickel slag using a milling machine by inserting the sample into a sample tube previously weighed in advance with a ratio of nickel slag samples to a ball mill of 1: 4 . Then the weighted nickel slag is inserted into the tube along with the ball mill. The tube is then placed on a milling machine. When the size of the slag nickel has been reduced, the sieving process continues using a sieve shaker up to \# 200.

After reducing the size of the nickel slag, proceed with the analysis of compounds and elements using $\mathrm{XRD}, \mathrm{ICP}$, and XRF.

\subsection{Experiment}

The process included the sample preparation (initial characterization and ball milling), the reduction, and The roasting process that performed in this study using coke as reductor. Preparation was done by weighing 2 grams of reductor as well as nickel slag and additives $\mathrm{Na}_{2} \mathrm{SO}_{4} 20$ gram each for a ratio of 1 : 1 and weighing for comparison between slag nickel and additives of 1:2 and 2: 1. Each of the weighed samples was mixed and separated into 6 reaction tubes comprising 3 additive-free tubes and 3 test tubes with additives according to their ratio ratios. Each tube is then inserted into the plastic and stirred so that the reducing agents, additives and nickel are evenly mixed. After the mixture is evenly mixed, the sample is put into crucible and on the top of it closed using glasswool which is aimed so that the sample contained in crucible is not directly oxidized.

Crucible which has been covered by glasswool then given charcoal on the top so that the roasting process can occur evenly. Then, crucible is placed inside the muffle furnace with operating temperature of $800^{\circ} \mathrm{C}, 900^{\circ} \mathrm{C}$ and $1000^{\circ} \mathrm{C}$ for 1 hour. After the roasting process finish, crucible is removed from the muffle furnace using iron bars and allowed to stand before the samples contained therein are then removed and weighed.

\section{Result and discussion}

\subsection{Slag Nickel Characterization}

Phase identification of nickel slag is carried out using XRF, ICP OES, and XRD. This nickel slag has been done size reduction and sieved with a size of 200 mesh. The result of the XRF test can be seen in Table 1 .

Table 1. Result of XRF test Nickel Slag

\begin{tabular}{|c|c|}
\hline Element & Content \\
\hline $\mathrm{Si}$ & $25,02 \%$ \\
\hline $\mathrm{Fe}$ & $7,20 \%$ \\
\hline $\mathrm{Co}$ & $64 \mathrm{ppm}$ \\
\hline $\mathrm{Ni}$ & $430,6 \mathrm{ppm}$ \\
\hline
\end{tabular}

$\mathrm{XRF}$ testing will produce list of elements that is contained in the nickel slag. From the table, we can see that the dominant elements are $\mathrm{Si}$ and Fe. Another test that used to identify phase contained in nickel slag is ICP OES. The result of nickel slag testing by ICP OES can be seen in Table 2 .

Table 2. Result of ICP OES Test Nickel Slag

\begin{tabular}{|c|c|}
\hline Element & Content (\%) \\
\hline $\mathrm{Si}$ & 0,004112 \\
\hline $\mathrm{Fe}$ & 6,460345 \\
\hline $\mathrm{Co}$ & 0,0042 \\
\hline $\mathrm{Ni}$ & 0,101 \\
$\mathrm{Mg}$ & 13,0383 \\
\hline
\end{tabular}

The data obtained by XRD PANalitycal Empyrean

\footnotetext{
*Corresponding author: jwsono@metal.ui.ac.id
} 
testing is processed using software named HighScore Plus and the result can be seen in Figure 1 and Table 3. In this test, there is a restriction in the search of compound contained in slag nickel. The compound sought in HighScore Plus software are only compounds that containing iron, magnesium, and silica.
The results of this test will produce peaks indicating the compounds contained in the nickel slag. The higher peak formed indicates more phases found in nickel slag, so from the peak analysis the dominant phase in the nickel slag is Fe-rich Forsterite $\left(\mathrm{FeMgSiO}_{4}\right)$. There are also Olivine $\left(\mathrm{NiMg}_{2} \mathrm{SiO}_{4}\right)$, Quartz $\left(\mathrm{SiO}_{2}\right)$ and Fayalite $\left(\mathrm{Fe}_{2} \mathrm{SiO}_{4}\right)$.
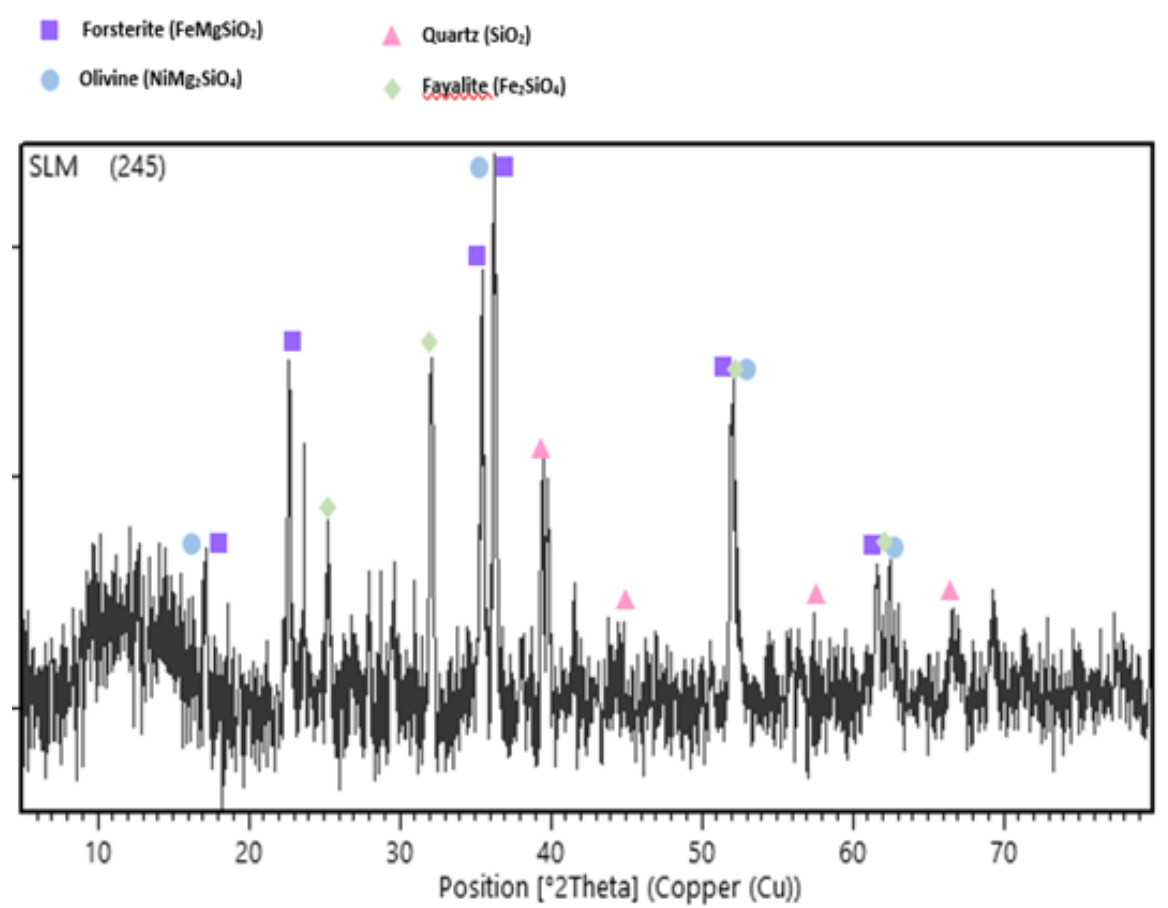

Fig. 1. Result of XRD Test of Nickel Slag

Table 3. Semi-Quant Data Calculation of Nickel Slag by HighScore Plus

\begin{tabular}{|c|c|c|}
\hline Compound & $\begin{array}{c}\text { Chemical } \\
\text { Formula }\end{array}$ & Semi-Quant (\%) \\
\hline $\begin{array}{c}\text { Fe-rich } \\
\text { Forsterite }\end{array}$ & $\mathrm{FeMgSiO}_{4}$ & 42,7 \\
\hline Olivine & $\mathrm{NiMg}_{2} \mathrm{SiO}_{4}$ & 22,8 \\
\hline Quartz & $\mathrm{SiO}_{2}$ & 4,7 \\
\hline Fayalite & $\mathrm{Fe}_{2} \mathrm{Si}_{4}$ & 29,8 \\
\hline
\end{tabular}

\subsection{Characterization of Coal as Reductor}

Nickel slag pyrometallurgy process in this research is done by coal as the redactor where its composition is got from BATAN and can be seen in Table 4. The pyrometallurgy process is also done by $\mathrm{Na}_{2} \mathrm{SO}_{4}$ as additive.

\footnotetext{
* Corresponding author: jwsono@metal.ui.ac.id
}

\subsection{Effect of Temperature}

\subsubsection{Effect of Temperature to Nickel Slag}

The temperature of roasting process has great effect to the change of compound composition which contained in nickel slag. The change of compound 
composition determined by activation energy each compound to get free then form a new compound.

Tabel 2. Coal Specification That is Used as Reductor

\begin{tabular}{|c|c|c|c|c|c|c|}
\hline Komponen & $\begin{array}{c}\text { Zat } \\
\text { Terbang }\end{array}$ & Abu & $\begin{array}{c}\text { Fixed } \\
\text { Carbon }\end{array}$ & S & Moisture & $\begin{array}{c}\text { Calories Value } \\
\text { (Cal/g) }\end{array}$ \\
\hline$\%$ & 36,26 & 14,39 & 36,92 & 0,91 & 14,4 & 6047 \\
\hline
\end{tabular}

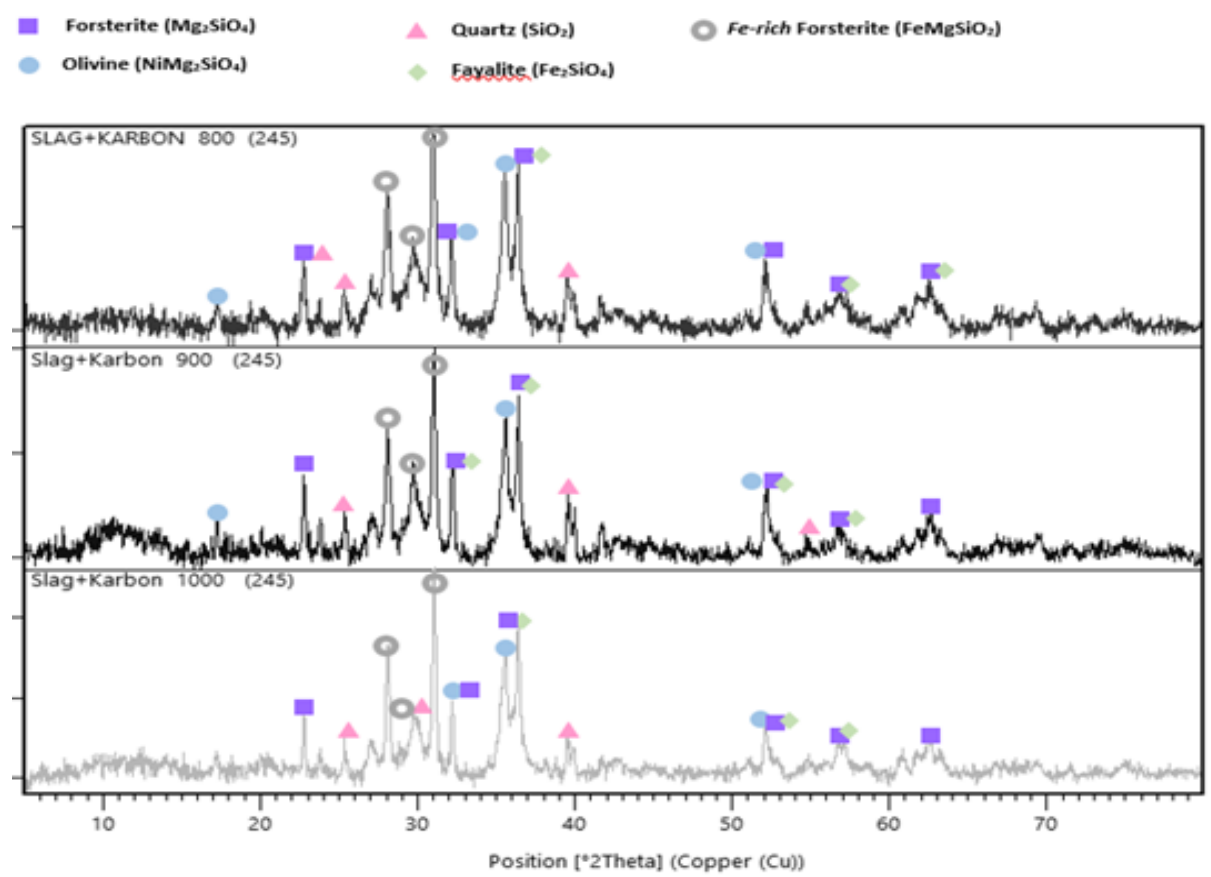

Fig. 2. Result of XRD Test Nickel Slag that is done in Different Temperature

Table 5. Composition of nickel slag roasted at $800^{\circ} \mathrm{C}$

\begin{tabular}{|c|c|c|}
\hline \multicolumn{3}{|c|}{$\mathbf{8 0 0}^{\mathbf{}} \mathbf{C}$} \\
\hline Compound & Chemical Formula & Semi-Quant (\%) \\
\hline Fe-rich Forsterite & $\mathrm{FeMgSiO}_{2}$ & $21,40 \%$ \\
\hline Forsterite & $\mathrm{Mg}_{2} \mathrm{SiO}_{4}$ & $19,90 \%$ \\
\hline Olivine & $\mathrm{NiMg}_{2} \mathrm{SiO}_{4}$ & $25 \%$ \\
\hline Fayalite & $\mathrm{Fe}_{2} \mathrm{SiO}_{4}$ & $29 \%$ \\
\hline Quartz & $\mathrm{SiO}_{2}$ & $4,60 \%$ \\
\hline
\end{tabular}

Table 6. Composition of nickel slag roasted at $900^{\circ} \mathrm{C}$

\begin{tabular}{|c|c|c|}
\hline \multicolumn{3}{|c|}{$\mathbf{9 0 0}^{\mathbf{C}}$} \\
\hline Compound & Chemical Formula & Semi-Quant (\%) \\
\hline Fe-rich Forsterite & $\mathrm{FeMgSiO}_{2}$ & $21,50 \%$ \\
\hline Forsterite & $\mathrm{Mg}_{2} \mathrm{SiO}_{4}$ & $20,70 \%$ \\
\hline Olivine & $\mathrm{NiMg}_{2} \mathrm{SiO}_{4}$ & $22,90 \%$ \\
\hline Fayalite & $\mathrm{Fe}_{2} \mathrm{SiO}_{4}$ & $30,10 \%$ \\
\hline Quartz & $\mathrm{SiO}_{2}$ & $4,70 \%$ \\
\hline
\end{tabular}

*Corresponding author: jwsono@metal.ui.ac.id 
Table 7. Composition of nickel slag roasted at $1000^{\circ} \mathrm{C}$

\begin{tabular}{|c|c|c|}
\hline \multicolumn{3}{|c|}{$\mathbf{1 0 0 0}^{\mathbf{C}}$} \\
\hline Compound & Chemical Formula $^{\text {Semi-Quant (\%) }}$ \\
\hline Fe-rich Forsterite & $\mathrm{FeMgSiO}_{2}$ & $21,40 \%$ \\
\hline Forsterite & $\mathrm{Mg}_{2} \mathrm{SiO}_{4}$ & $22,10 \%$ \\
\hline Olivine & $\mathrm{NiMg}_{2} \mathrm{SiO}_{4}$ & $23,10 \%$ \\
\hline Fayalite & $\mathrm{Fe}_{2} \mathrm{SiO}_{4}$ & $28,40 \%$ \\
\hline Quartz & $\mathrm{SiO}_{2}$ & $5,00 \%$ \\
\hline
\end{tabular}

From the data above, can be seen the change of the composition of compounds contained in the slag nickel with temperature as variables without additive. As temperature increases, the composition of the compounds present in the nickel slag does not show significant changes and tends to remain. According to Rinanda et. al [8], the reduction process with temperature as variable with 1 hour holding time with increasing temperature, the composition of $\mathrm{SiO}_{2}$ compounds tends to remain, comparable with other compounds present in nickel slag which tend to remain in line with the increasing of reduction temperature. This is because the $\mathrm{SiO}_{2}$ compound undergoes a change reaction from silica to silicon according to equation 4 .

$$
\mathrm{SiO}_{2(\mathrm{~s})}+\mathrm{C}_{(\mathrm{s})}=\mathrm{Si}_{(\mathrm{l})}+2 \mathrm{CO}_{(\mathrm{g})}
$$

\subsubsection{Effect of Temperature to Nickel Slag with additive (Na2SO4)}

To see the effect of temperature to enhance grade of valuable element in nickel slag with use of Sodium Sulphate $\left(\mathrm{Na}_{2} \mathrm{SO}_{4}\right)$ as additive by the ratio $1: 1$, reduction done with many temperature. The enhancement of valuable element expected to be done at optimum temperature.

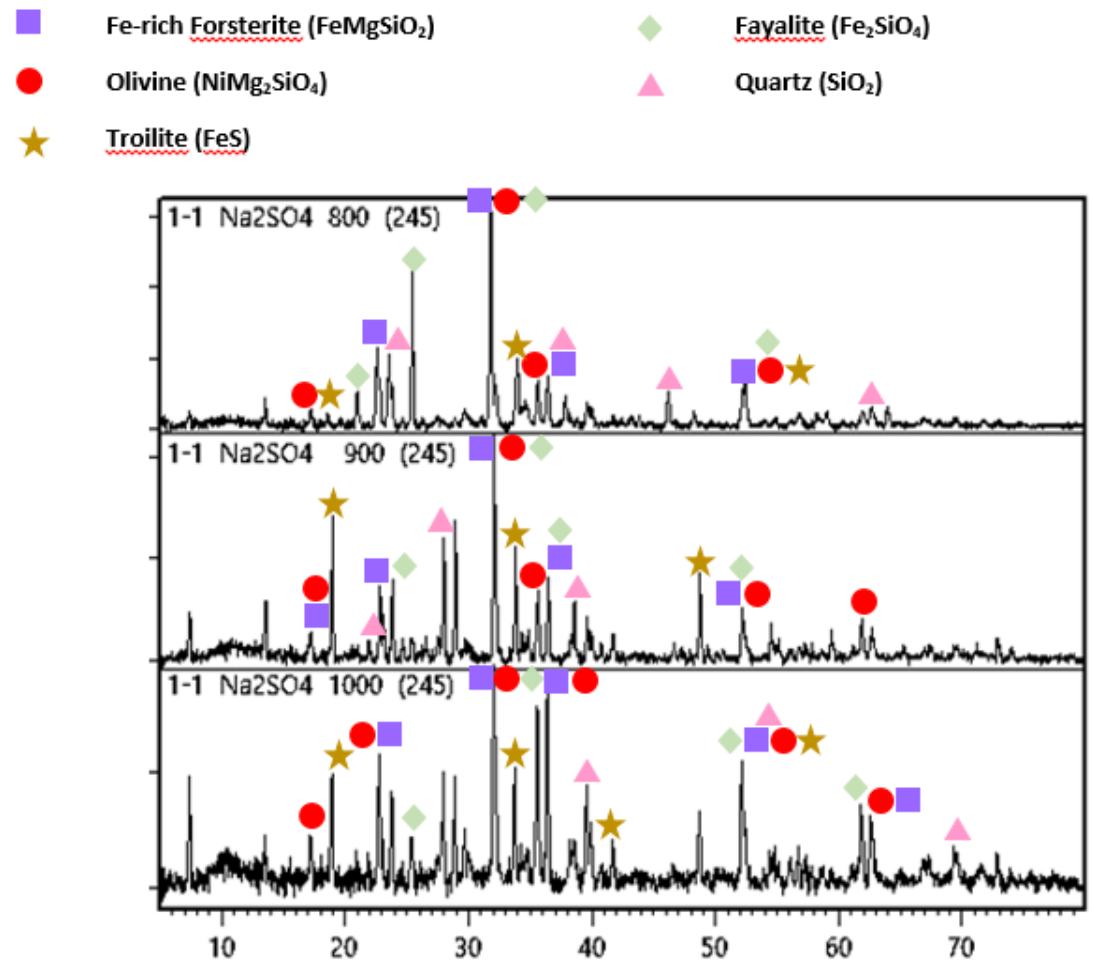

Fig. 3. Result of reduction process with addition of $\mathrm{Na}_{2} \mathrm{SO}_{4}$ to nickel slag with ratio 1:1

\footnotetext{
* Corresponding author: jwsono@metal.ui.ac.id
} 
Table 8. Composition of nickel slag roasted at $800^{\circ} \mathrm{C}$ with addition of $\mathrm{Na}_{2} \mathrm{SO}_{4}$

\begin{tabular}{|c|c|c|}
\hline \multicolumn{3}{|c|}{$\mathbf{8 0 0}^{\mathbf{C}}$} \\
\hline Compound & $\begin{array}{c}\text { Chemical } \\
\text { Formula }\end{array}$ & $\begin{array}{c}\text { Semi-Quant } \\
\text { (\%) }\end{array}$ \\
\hline $\begin{array}{c}\text { Fe-rich } \\
\text { Forsterite }\end{array}$ & $\mathrm{FeMgSiO}_{2}$ & 16,5 \\
\hline Troilite & $\mathrm{FeS}$ & 36,6 \\
\hline Olivine & $\mathrm{NiMg}_{2} \mathrm{SiO}_{4}$ & 19,9 \\
\hline Fayalite & $\mathrm{Fe}_{2} \mathrm{SiO}_{4}$ & 23,3 \\
\hline Quartz & $\mathrm{SiO}_{2}$ & 3,7 \\
\hline
\end{tabular}

Tabel 9. Composition of nickel slag roasted at $900^{\circ} \mathrm{C}$ with addition of $\mathrm{Na}_{2} \mathrm{SO}_{4}$

\begin{tabular}{|c|c|c|}
\hline \multicolumn{3}{|c|}{$\mathbf{9 0 0}^{0} \mathrm{C}$} \\
\hline $\begin{array}{c}\text { Compound } \\
\text { Formula }\end{array}$ & $\begin{array}{c}\text { Semi-Quant } \\
\text { (\%) }\end{array}$ \\
\hline $\begin{array}{c}\text { Forsterite } \\
\text { Troilite }\end{array}$ & $\mathrm{FeMgSiO}_{2}$ & 16,8 \\
\hline Olivine & $\mathrm{NiMg}_{2} \mathrm{SiO}_{4}$ & 20,3 \\
\hline Fayalite & $\mathrm{Fe}_{2} \mathrm{SiO}_{4}$ & 22,9 \\
\hline Quartz & $\mathrm{SiO}_{2}$ & 2,6 \\
\hline
\end{tabular}

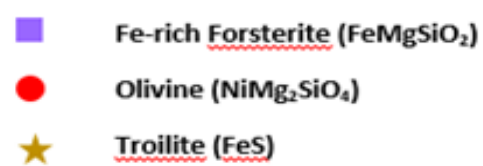

Table 10. Composition of nickel slag roasted at $1000^{\circ} \mathrm{C}$ with addition of $\mathrm{Na}_{2} \mathrm{SO}_{4}$

\begin{tabular}{|c|c|c|}
\hline \multicolumn{3}{|c|}{$\mathbf{1 0 0 0}^{\mathbf{0}} \mathrm{C}$} \\
\hline Compound & $\begin{array}{c}\text { Chemical } \\
\text { Formula }\end{array}$ & $\begin{array}{c}\text { Semi-Quant } \\
\text { (\%) }\end{array}$ \\
\hline $\begin{array}{c}\text { Fe-rich } \\
\text { Forsterite }\end{array}$ & $\mathrm{FeMgSiO}_{2}$ & 17,5 \\
\hline Troilite & $\mathrm{FeS}$ & 39,2 \\
\hline Olivine & $\mathrm{NiMg}_{2} \mathrm{SiO}_{4}$ & 20,7 \\
\hline Fayalite & $\mathrm{Fe}_{2} \mathrm{SiO}_{4}$ & 21,8 \\
\hline Quartz & $\mathrm{SiO}_{2}$ & 0,8 \\
\hline
\end{tabular}

Based on data above, it can be seen that with the addition of $\mathrm{Na}_{2} \mathrm{SO}_{4}$ to nickel slag with the variation of the reduction temperature at $800^{\circ} \mathrm{C}, 900^{\circ} \mathrm{C}$, and $1000^{\circ} \mathrm{C}$ with holding time of 1 hour, the higher the temperature there will be less $\mathrm{SiO}_{2}$ present in nickel slag [9]. It can also be seen that the content of other compound which is Fayalite decreased. This is due to Fe being liberated at the time of reduction so that when $\mathrm{Na}_{2} \mathrm{SO}_{4}$ added, the liberated $\mathrm{Fe}$ will bond to $\mathrm{S}$ to form Troilite $(\mathrm{FeS})$.

\subsubsection{Effect of Ratio of Additive to Nickel Slag} In the previous test it can be seen that the most optimal temperature for reducing nickel slag is at $1000^{\circ} \mathrm{C}$. Therefore, to see the effect of adding additive to the composition of compounds present in slag nickel, a reduction process done with a fixed temperature of $1000^{\circ} \mathrm{C}$ with a holding time of 1 hour.

Fayalite $\left(\mathrm{Fe}_{2} \mathrm{SiO}_{4}\right)$

Quartz $\left(\mathrm{SiO}_{2}\right)$

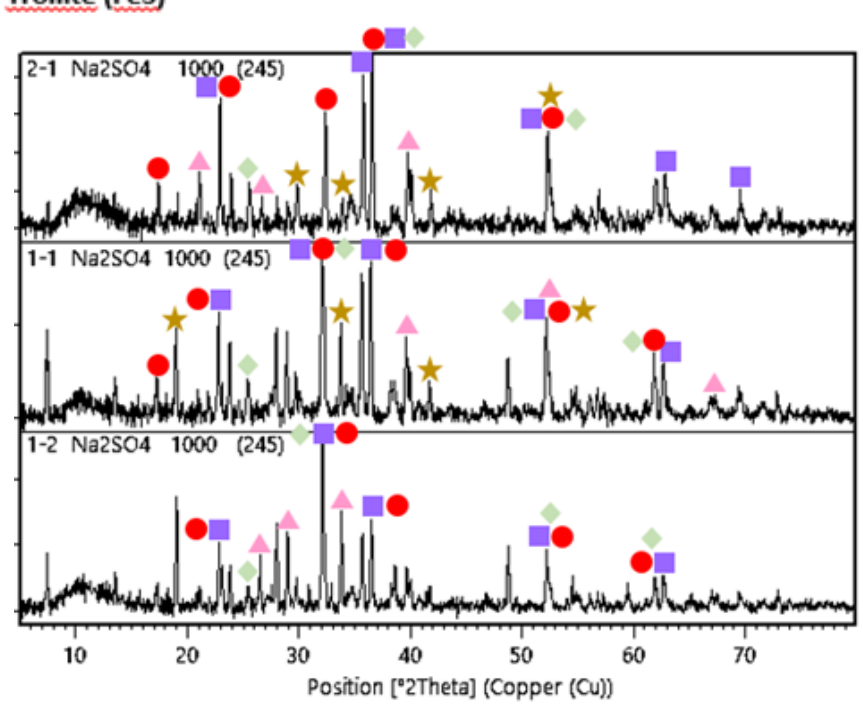

Fig. 4. Result of Variation of Additive Added to Nickel Slag

\footnotetext{
*Corresponding author: jwsono@metal.ui.ac.id
} 
Table 11. Result of Composition Nickel Slag added by $\mathrm{Na}_{2} \mathrm{SO}_{4}$ by ratio 2:1

\begin{tabular}{|c|c|c|}
\hline \multicolumn{3}{|c|}{ Slag : Additive $=2: 1$} \\
\hline Compound & Chemical Formula & Semi-Quant (\%) \\
\hline Fe-rich Forsterite & $\mathrm{FeMgSiO}_{2}$ & 17,4 \\
\hline Troilite & $\mathrm{FeS}$ & 39,1 \\
\hline Olivine & $\mathrm{NiMg}_{2} \mathrm{SiO}_{4}$ & 18,2 \\
\hline Fayalite & $\mathrm{Fe}_{2} \mathrm{SiO}_{4}$ & 23,2 \\
\hline Quartz & $\mathrm{SiO}_{2}$ & 2,1 \\
\hline
\end{tabular}

Table 12. Result of Composition Nickel Slag added by $\mathrm{Na}_{2} \mathrm{SO}_{4}$ by ratio 1:1

\begin{tabular}{|c|c|c|}
\hline \multicolumn{3}{|c|}{ Slag : Additive $=\mathbf{1 : 1}$} \\
\hline Compound & Chemical Formula & Semi-Quant (\%) \\
\hline Fe-rich Forsterite & $\mathrm{FeMgSiO}_{2}$ & 17,5 \\
\hline Troilite & $\mathrm{FeS}$ & 39,2 \\
\hline Olivine & $\mathrm{NiMg}_{2} \mathrm{SiO}_{4}$ & 20,7 \\
\hline Fayalite & $\mathrm{Fe}_{2} \mathrm{SiO}_{4}$ & 21,8 \\
\hline Quartz & $\mathrm{SiO}_{2}$ & 0,8 \\
\hline
\end{tabular}

Table 13. Result of Composition Nickel Slag added by $\mathrm{Na}_{2} \mathrm{SO}_{4}$ by ratio 1:2

\begin{tabular}{|c|c|c|}
\hline \multicolumn{3}{|c|}{ Slag : Additive = 1:2 } \\
\hline Compound & Chemical Formula & Semi-Quant (\%) \\
\hline Fe-rich Forsterite & $\mathrm{FeMgSiO}_{2}$ & 15,3 \\
\hline Troilite & $\mathrm{FeS}$ & 46,3 \\
\hline Olivine & $\mathrm{NiMg}_{2} \mathrm{SiO}_{4}$ & 16,3 \\
\hline Fayalite & $\mathrm{Fe}_{2} \mathrm{SiO}_{4}$ & 21,4 \\
\hline Quartz & $\mathrm{SiO}_{2}$ & 0,7 \\
\hline
\end{tabular}

\section{Conclusion}

The result of XRD test of slag nickel reduced at temperatures of $800^{\circ} \mathrm{C}, 900^{\circ} \mathrm{C}$, and $1000^{\circ} \mathrm{C}$ without additive indicates no reduction of iron or nickel occurring from Fe-rich Forsterite $\left(\mathrm{FeMgSiO}_{4}\right)$ and Olivine $\left(\mathrm{NiMg}_{2} \mathrm{SiO}_{4}\right)$. The result of XRD test of slag reduction which has been reduced at temperatures of $800^{\circ} \mathrm{C}, 900^{\circ} \mathrm{C}$, and $1000^{\circ} \mathrm{C}$ with the addition of $\mathrm{Na}_{2} \mathrm{SO}_{4}$ shows that with the increase of temperature, Fe-rich Forsterite $\left(\mathrm{FeMgSiO}_{4}\right)$ phase changes into Troillite (FeS). The result of XRD test of slag reduction that has been reduced at $1000^{\circ} \mathrm{C}$ with ratio between nickel slag with $\mathrm{Na}_{2} \mathrm{SO}_{4}$ additive 2:1, 1:1 and 1:2 shows as $\mathrm{Na}_{2} \mathrm{SO}_{4}$ additive increase, the decrease of silica oxide $\left(\mathrm{SiO}_{2}\right)$ occurred.

\footnotetext{
*Corresponding author: jwsono@metal.ui.ac.id
}

The authors also wish to thank the Ministry of Research Technology and Higher Education and Directorate of Research and Community Engagement, Universitas Indonesia, under PITTA Research Grants Contract No. 2460/UN2.R3.1/HKP05.00/2018 for the financial support of this research.

\section{References}

1. G. M. Mudd, "Global trends and environmental issues in nickel mining: Sulfides versus laterites," Ore Geol. Rev., vol. 38, no. 1-2, pp. 9-26, 2010.

2. J. Pan, G. L. Zheng, D. Q. Zhu, and X. L. 
Zhou, "Utilization of nickel slag using selective reduction followed by magnetic separation," Trans. Nonferrous Met. Soc. China (English Ed., vol. 23, no. 11, pp. 3421-3427, 2013.

3. Z. Guo, D. Zhu, J. Pan, and F. Zhang, "Mineralogical Characteristics and Preliminary Beneficiation of Nickel Slag from Reduction Roasting-Ammonia Leaching," Minerals, vol. 7, no. 6, p. 98, 2017.

4. C. Cao, Z. Xue, and H. Duan, "Making Ferronickel from Laterite Nickel Ore by Coal-Based Self-Reduction and High Temperature Melting Process," Int. J. Nonferrous Metall., vol. 5, pp. 9-15, 2016.

5. S. Wang, C. Wang, Q. Wang, W. Ni, and K. $\mathrm{Li}$, "Optimization and microstructure study of the reduction of nickel smelting slag mixed with calcium carbide slag and coke dust for recovering iron," Chem. Eng. Trans., vol. 62, pp. 55-60, 2017.

6. F. Huang, Y. Liao, J. Zhou, Y. Wang, and H. $\mathrm{Li}$, "Selective recovery of valuable metals from nickel converter slag at elevated temperature with sulfuric acid solution," Sep. Purif. Technol., vol. 156, pp. 572-581, 2015.

7. Y. Ma, X. Du, Y. Shen, G. Li, and M. Li, "Crystallization and Beneficiation of Magnetite for Iron Recycling from Nickel Slags by Oxidation-Magnetic Separation," Metals (Basel)., vol. 7, no. 8, p. 321, 2017.

8. R. Rahmat and A. Maksum, "Effects of $\mathrm{Na} 2 \mathrm{SO} 4$ addition on the selective reduction of limonite ore from Southeast Sulawesi Effects of $\mathrm{Na} 2 \mathrm{SO} 4$ addition on the selective reduction of limonite ore from Southeast Sulawesi," IOP Conf. Ser. Earth Environ. Sci., vol. 105, 2017.

9. A. Maksum and J. W. Soedarsono, "Effects of temperature on the direct reduction of Southeast Sulawesi 's limonite ore," IOP Conf. Ser. Earth Environ. Sci., vol. 105, 2017.

\footnotetext{
* Corresponding author: jwsono@metal.ui.ac.id
} 